\title{
Storage Stability of Cow and Caprine Milk Dahi Incorporated with $\beta$ - Casein Bioactive Peptides
}

\author{
H. Devaraja Naik ${ }^{1 *}$, M. Venkatesh ${ }^{2}$ and R. Prabha ${ }^{3}$ \\ ${ }^{1}$ Department of Livestock products Technology, Veterinary College, Karnataka Veterinary, \\ Animal and Fisheries Science University (Bidar), Hassan, India \\ ${ }^{2}$ Department of Dairy Technology, ${ }^{3}$ Department of Dairy Microbiology, Dairy Science \\ College, Karnataka Veterinary, Animal and Fisheries Science University (Bidar), Hebbal \\ Bengaluru, India \\ *Corresponding author
}

\section{A B S T R A C T}

\section{Keywords}

Caprine milk, Dahi quality, Casein hydrolysates,

Bioactive peptides, Physical, Chemical and microbiological test

\section{Article Info}

Accepted:

15 October 2018

Available Online:

10 November 2018
Dahi was prepared using cow and caprine milk and the experiment was carried out to assess the quality Dahi during storage from two distinct species of milk. The cow samples were collected from Dairy farm, KVAFSU, Hebbal, Bengaluru and caprine milk samples were collected from Sinchana goat and sheep farm, Marenahalli village (Bengaluru Rural District) and Yashodhavana Goat Farm (Mysuru) were used. The Dahi prepared were incorporated with different level of Bioactive peptides (BAPs) to studied their antibacterial and antioxidative role during storage as a index for storage stability. The Dahi prepared from cow was used as a control and the caprine milk Dahi was incorporated with different level of $\beta$-casein hydrolysed Bioactive Peptides (BAP's) were 1.0, 1.5 and 2.0 per cent respectively. The prepared Dahi samples were used to evaluate their quality of the Dahi were physical, chemical and microbiological parameters. It was found that the caprine milk Dahi incorporated with $\beta$-casein hydrolysates of BAPs were optimised to the level of 1.5 per cent were found statistically significant $(\mathrm{p}<0.05)$ with control and other samples. It extends their shelf life up to 4 days compare to control was 3 days at room temperature $27^{\circ}$ C).

\section{Introduction}

The livestock sector has emerged as vital sector for ensuring a more inclusive and sustainable agricultural system in India. The livestock sector of India is one of the largest in the world. The milk production of our nation was provisionally estimated was 176.35 million tonnes during in 2017-18. The goat is one of the main contributors of dairy and it produces about more than 2 per cent of the world's total annual milk supply. India has witnessed an increasing trend of goat milk production with a growth rate of 3.82 per cent during 2015 - 16 (www.nddb.org). Caprine milk fat have smaller fat globules, it is easier to digest than cow milk. Further, the exact composition varies according to many factors like breeds, individual animal, lactation, health condition, environmental condition etc. (Yadav et al., 2016). Caprine milk and its products are highly nutritious, health benefits 
and widely consumed in many other parts of the world. Therefore, awareness about advantage of consumption of goat milk should be popularized in India so that production and utilization of goat milk could be enhanced. Dahi is a fermented Indian dairy product consumed by larger section of peoples throughout the country, either as a part of daily diet or as refreshing beverage. About 7 per cent of total milk production is used for Dahi making. Dahi is produced by using mixed mesophilic cultures of Lactococcus lactis ssp lactis, L. lactis ssp cremoris, L.lactis ssp. diacetylactis along with Lecunostoc species and lactose fermenting yeasts. Dahi is well recognized for their therapeutic properties, particularly in curing gastrointestinal disorders (Mudgal and Prajapati, 2017). The enzymatic hydrolysis of casein obtained by urea filtration produced bioactive peptides (BAPs) plays important role in metabolic regulation. The released peptides can be easily incorporated in to fermented milk products to perform many vital physiological function such as antihypertensive, anti-oxidant, anti-cancer, antimicrobial, opiod activities, anti-oxidative and immunomodulatory (Naik et al., 2013). Further, incorporation of hydrolysate enhanced the growth of $S$. thermophilus and increases the acidity, as a result of that reducing the fermentation time, and growth of probiotic bacteria. Further there was survival of probiotic bacteria was improved when milk was added with hydrolysate $\left(0.25\right.$ to $\left.4 \mathrm{~g} \mathrm{~L}^{-1}\right)$. The sensory evaluation of the goat milk with/without transglutaminase (TGase, at ranges of $0-4$ units/g protein), TGase treated Labneh (a concentrated type of yogurt) the overall scores of the sensory properties showed that significant differences were observed among samples for appearance, brightness, texture, odour, flavour and consistence $(\mathrm{P}<0.05)$. The lowest overall score was detected for control labneh with value 12.45 while the highest overall score was detected for $2 \mathrm{U}$ TGase treated labneh sample (Alo glua and Oner, 2013). Plain dahi was in good condition up to 3 days of storage period and banana juice based dahi was up to 2 days only at room temperature (Kamruzzaman et al., 2002).

Many works have been done in different countries on quality of dahi prepared from different species milk especially on cow and buffalo where as limited work has been made on caprine milk dahi and available data was also scanty. Hence, an attempt has been made to bring new changes in the product by incorporating bioactive peptides in fermented product may enhances the physiological, biological and therapeutical values in the human diet.

\section{Materials and Methods}

\section{Milk samples}

The indigenous and exotic caprine breed milk samples were collected from Sinchana goat and sheep farm, Marenahalli village (Bengalru Rural Dist) and Yashodhavana Goat Farm (Mysuru) and cow milk samples were collected from Dairy Farm, Hebbal, KVAFSU Bengaluru.

\section{Starter culture}

The mixed starter culture consisting of Lactococcus lactis ssp. lactis, L. lactis ssp cremoris, L. lactis ssp diacetylactis along with Leuconostoc species were procured from the NDRI, Audugodi, Bengaluru.

\section{Trypsin enzymes}

2000 IU (Loba Chemicals Bovine Pancreas) a commercially available enzyme used for the hydrolysis of casein to obtain higher degree of hydrolysis (Enzyme substrate ratio of 1:25). 


\section{Fractionation of casein}

The fractionation of casein from acid whole casein (wet) was followed as per procedure of Hipp et al., (1952) on the basis of differential solubility in urea solution. Fractionation of whole casein from $6.6 \mathrm{M}$ urea to $4.63 \mathrm{M}$ urea yields a precipitate of $\alpha_{\mathrm{s}}$-casein and $\beta$ - casein is obtained by further dilution of the supernatant to $1.7 \mathrm{M}$ urea at $\mathrm{pH}$ of 4.7 .

\section{Preparation of casein fraction hydrolysates}

The $\beta$-casein $(\beta-\mathrm{CN})$ fractions of caprine milk was dispersed separately in distilled water at $40^{\circ} \mathrm{C}$ to give a 5 per cent $(\mathrm{w} / \mathrm{v})$ protein concentration and the $\mathrm{pH}$ of the solutions was adjusted to optimum as that of the enzymes using $0.1 \mathrm{~N} \mathrm{NaOH}$. The enzyme trypsin (10 $\mathrm{mg}$ of enzyme $/ 5 \mathrm{~g}$ of protein) at $\mathrm{pH} 8.0$ and temperature $40^{\circ} \mathrm{C}$ was maintained. Enzymatic hydrolysis of casein fractions was carried out at an enzyme- substrate (E: $S$ ) ratio of 1:25 (Nagamani, 2013).

\section{Degree of hydrolysis}

Degree of hydrolysis (DH) was determined by the $\mathrm{pH}$ stat method (Mcdonagh and Fitzgerald., 1998) with slight modification in temperature and strength of alkali used to keep the $\mathrm{pH}$ constant during hydrolysis.

Degree of Hydrolysis $(\mathrm{DH})=\mathrm{B} \times \mathrm{Nb} \times 1 / \alpha \mathrm{s} \times$ $1 / \mathrm{Mp} \times 1 /$ htot $\times 100$

Where,

$\mathrm{B}=$ Base consumption in $\mathrm{ml}$

$\mathrm{Nb}=$ Normality of Base (alkali)

$\mathrm{Mp}=$ Mass of protein in gram $(\mathrm{N} \times \mathrm{fN})$

htot $=$ Total number of peptide bonds in protein substrate (meq/g of protein for casein; htot $=8.2$ )

$\alpha=$ Average degree of dissociation of $\alpha-\mathrm{NH}_{2}$ groups $1 / \alpha$ factor was considered. $\alpha S=\frac{10^{\mathrm{pH}-\mathrm{pKa}}}{1+10^{\mathrm{pH}-\mathrm{pKa}}}$

For casein $\mathrm{pKa}=7.45$ at $\mathrm{pH} 7.5,1 / \alpha=1.89$.

\section{Isolation of Bio-active peptides (BAPs)}

The BAPs were isolated from $\beta$ - casein fractions by adapting the method of Fitz Gerald (1998) which is based on the principle that BAPs are soluble at $\mathrm{pH} 4.6$ and aggregated with divalent cat-ion such as calcium at neutral $\mathrm{pH}$ of 7.0. BAPs obtained by ethanol extraction were dried overnight in an oven maintained at a temperature of $70 \pm 1^{0}$ $\mathrm{C}$ and stored at $4^{0} \mathrm{C}$ before use. Hydrolysates of casein fractions were subjected for centrifugation (3000 $\mathrm{rpm} / 10 \mathrm{~min})$. The obtained supernatant was adjusted to $\mathrm{pH} 7.0$ then 1 per cent calcium chloride was added and kept for $1 \mathrm{~h}$. Ethanol (50 per cent v/v) was added to the supernatant to yield BAPs of $\beta$ casein fractions. The quantification of BAPs from casein fraction was carried out by adapting the method suggested by Bradford (1976).

\section{Statistical analysis}

Experimental data obtained in the study was analyzed by Randomized column block design as per the method described by Snedecor and Cochran (1983) to test for ' $F$ ' values to know the statistical significance. Critical Difference (CD) value was calculated to determine whether the treatment means were similar or not. The analysis was done using SPSS software package and MS Excel 2007.

\section{Results and Discussion}

Sensory characteristics of caprine milk Dahi incorporated with $\beta$-casein BAPs stored at room temperature $\left(30 \pm 1^{\circ} \mathrm{C}\right)$

Caprine milk dahi incorporated with 1.5 per cent $\beta$-casein BAPs showed the score of 8.49 , 
8.36 and 7.93 for colour and appearance 8.64, 8.54 and 8.23 for body and texture and 8.14, 8.10 and 8.05 for flavour and 8.48, 8.39 and 8.0 for overall acceptability at room temperature was presented in Table 2. The score of caprine milk Dahi flavour was statistically significant $(\mathrm{P} \leq 0.05)$ with the flavour of cow milk Dahi. These values are well within the range that was obtained by earlier workers Kamruzzaman et al., (2002) observed the organoleptic quality of Dahi for 3 days stored at room temperature and also Nikil Mahabalashetti, (2017) reported that the sensory quality of control and developed coconut and kiwi fruit pulp enriched Dahi stored at room temperature $\left(30 \pm 1^{0} \mathrm{C}\right)$ was unacceptable on $4^{\text {th }}$ day of storage.

Chemical quality of caprine milk Dahi incorporated with $\beta$-casein BAPs during storage at room temperature $\left(30 \pm 1^{0} \mathrm{C}\right)$

The $\mathrm{pH}$ and acidity (\%LA) of $\beta$-CN BAPs incorporated at 1.5 per cent was 5.0 and 0.69 per cent lactic acid (Table 1). There was a highly significant difference $(\mathrm{P} \leq 0.05)$ between the $\mathrm{pH}$ and acidity of caprine milk Dahi and cow Dahi. Similar findings was made by Manmatha (2014) that the $\mathrm{pH}$ and acidity of caprine milk yoghurt was 4.8 and 1.05 per cent lactic acid respectively.

Free Fatty Acids and Soluble Nitrogen content of caprine milk Dahi incorporated with $\beta$-casein BAPs during storage at room temperature $\left(30 \pm 1^{0} \mathrm{C}\right)$

The development of Free Fatty Acid (FFA) value of oleic acid content $\beta$-casein at 1.5 per cent BAPs level of caprine milk dahi (Table 3 ) were $7.3,10.74,11.30$ and 13.26 respectively and soluble nitrogen content was $0.09,0.10$, 0.17 for $1^{\text {st }}, 2^{\text {nd }}$ and $3^{\text {rd }}$ day. The cow milk dahi sample found higher soluble nitrogen content and lower FFA value. Incorporated BAPs have extended their shelf life to $4^{\text {th }}$ day stored at room temperature $\left(30 \pm 1{ }^{0} \mathrm{C}\right)$. The results were agreed with Manmatha (2014) FFA value was 13.02 per cent and soluble nitrogen 0.26 per cent for caprine milk yoghurt.

Table.1 Chemical quality of caprine milk Dahi incorporated with $\beta$-casein BAPs during storage at $30 \pm 1^{\circ} \mathrm{C}$

\begin{tabular}{|c|c|c|c|c|c|c|c|c|}
\hline \multirow[t]{2}{*}{ Sample } & \multicolumn{2}{|c|}{ Fresh } & \multicolumn{2}{|c|}{$1^{\text {st }}$ Day } & \multicolumn{2}{|c|}{$2^{\text {nd }}$ Day } & \multicolumn{2}{|c|}{$3^{\text {rd }}$ Day } \\
\hline & pH & $\begin{array}{l}\text { Acidity } \\
\text { (\% LA) }\end{array}$ & pH & $\begin{array}{l}\text { Acidity } \\
\text { (\% LA) }\end{array}$ & pH & $\begin{array}{l}\text { Acidity } \\
\text { (\% LA) }\end{array}$ & pH & $\begin{array}{l}\text { Acidity } \\
\text { (\% LA) }\end{array}$ \\
\hline C & $5.2^{\mathrm{a}}$ & $0.68^{\mathrm{a}}$ & $5.0^{\mathrm{a}}$ & $0.78^{\mathrm{a}}$ & $4.9 \mathrm{~b}$ & $1.12^{b}$ & \multirow{3}{*}{-} & \multirow{3}{*}{5} \\
\hline C1 & $5.0^{\mathrm{a}}$ & $0.71^{\mathrm{a}}$ & $4.9^{a}$ & $0.79^{\mathrm{a}}$ & $4.8^{b}$ & $1.15^{b}$ & & \\
\hline $\mathrm{C2}$ & $5.1^{\mathrm{a}}$ & $0.69^{\mathrm{a}}$ & $5.0^{\mathrm{a}}$ & $0.76^{\mathrm{a}}$ & $4.9^{b}$ & $1.10^{\mathrm{b}}$ & & \\
\hline C3 & $5.0^{\mathrm{a}}$ & $0.67^{\mathrm{a}}$ & $5.0^{\mathrm{a}}$ & $0.69^{a}$ & $4.9^{b}$ & $0.70^{\mathrm{a}}$ & $4.8^{\mathrm{b}}$ & $1.11^{\mathrm{b}}$ \\
\hline C4 & $4.9^{\mathrm{a}}$ & $0.72^{\mathrm{a}}$ & $4.8^{\mathrm{a}}$ & $0.78^{\mathrm{a}}$ & $4.7^{b}$ & $1.12^{b}$ & - & - \\
\hline $\mathrm{CD}(\mathrm{P} \leq 0.05)$ & 0.032 & 0.042 & 0.032 & 0.051 & 0.036 & 0.024 & - & - \\
\hline
\end{tabular}

- All values are average of three trials

- Similar superscripts indicates non-significance at the corresponding critical difference on a row

$>\mathrm{C}_{0}$ : Control cow milk Dahi

$>\mathrm{C}_{1}$ : Caprine milk Dahi

$>\mathrm{C}_{2}$ : Dahi incorporated with $\beta$-casein BAPs at 1.0 per cent level

$>\mathrm{C}_{3}$ : Dahi incorporated with $\beta$-casein BAPs at 1.5 per cent level

$\mathrm{C}_{4}$ : Dahi incorporated with $\beta$-casein BAPs at 2.0 per cent level 


\section{Int.J.Curr.Microbiol.App.Sci (2018) 7(11): 2011-2019}

Table.2 Sensory attributes of caprine milk Dahi incorporated with $\beta$-casein BAPs during storage at $30 \pm 1{ }^{\circ} \mathrm{C}$

\begin{tabular}{|c|c|c|c|c|c|c|c|c|c|c|c|c|c|c|c|c|}
\hline \multirow[t]{2}{*}{ Product } & \multicolumn{4}{|c|}{ Colour \& Appearance } & \multicolumn{4}{|c|}{ Body \& Texture } & \multicolumn{4}{|c|}{ Flavour } & \multicolumn{4}{|c|}{ Overall acceptability } \\
\hline & 1 & 2 & 3 & 4 & 1 & 2 & 3 & 4 & 1 & 2 & 3 & 4 & 1 & 2 & 3 & 4 \\
\hline $\mathrm{C}$ & $8.54^{\mathrm{a}}$ & $8.10^{\mathrm{a}}$ & \multirow{3}{*}{ 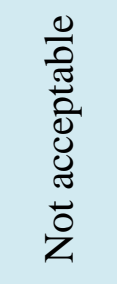 } & & $8.72^{\mathrm{a}}$ & $7.92^{b}$ & \multirow{3}{*}{ 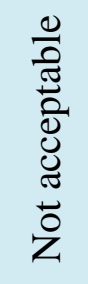 } & & $8.58^{\mathrm{a}}$ & $8.12^{\mathrm{a}}$ & \multirow{3}{*}{ 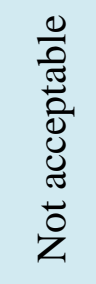 } & - & $8.46^{\mathrm{a}}$ & $7.92^{b}$ & \multirow{3}{*}{ 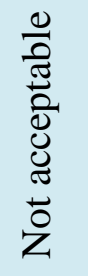 } & - \\
\hline $\mathrm{C} 1$ & $8.32^{b}$ & $7.58^{b}$ & & & $8.35^{\mathrm{b}}$ & $7.78^{b}$ & & & $7.87^{\mathrm{b}}$ & $7.76^{\mathrm{b}}$ & & - & $8.36^{\mathrm{b}}$ & $7.59^{\mathrm{b}}$ & & - \\
\hline $\mathrm{C} 2$ & $8.36^{\mathrm{b}}$ & $7.60^{b}$ & & & $8.32^{b}$ & $7.82^{b}$ & & & $7.84^{\mathrm{a}}$ & $7.80^{\mathrm{b}}$ & & - & $8.32^{\mathrm{b}}$ & $7.49^{b}$ & & - \\
\hline $\mathrm{C} 3$ & $8.49^{\mathrm{a}}$ & $8.36^{\mathrm{a}}$ & $7.93^{b}$ & NA & $8.64^{\mathrm{a}}$ & $8.54^{\mathrm{a}}$ & 8.23 & NA & $8.14^{\mathrm{a}}$ & $8.10^{\mathrm{a}}$ & 8.05 & $\mathrm{NA}$ & $8.48^{\mathrm{a}}$ & $8.39^{\mathrm{a}}$ & 8.0 & NA \\
\hline $\mathrm{C} 4$ & $8.36^{\mathrm{b}}$ & $7.35^{\mathrm{b}}$ & NA & & $8.34^{\mathrm{a}}$ & $7.89^{b}$ & NA & & $7.89^{b}$ & $7.98^{\mathrm{b}}$ & NA & & $8.36^{\mathrm{a}}$ & $7.59^{\mathrm{b}}$ & NA & - \\
\hline $\mathrm{CD}(\mathrm{P} \leq 0.05)$ & 0.48 & 0.56 & - & - & 0.82 & 0.036 & - & - & 0.048 & 0.052 & - & - & 0.39 & 0.028 & - & - \\
\hline
\end{tabular}

- All values are average of three trials

- Similar superscripts indicates non-significance at the corresponding critical difference on a row

- NA - Not acceptable

$>$ C0: Control cow milk Dahi

$>$ C1: Caprine milk Dahi

$>$ C2: Dahi incorporated with $\beta$-casein BAPs at 1.0 per cent level

$>$ C3: Dahi incorporated with $\beta$-casein BAPs at 1.5 per cent level

$>$ C4: Dahi incorporated with $\beta$-casein BAPs at 2.0 per cent level 
Table.3 Microbiological quality of caprine milk Dahi incorporated with $\beta$-casein BAPs during storage at $30 \pm 1^{0} \mathrm{C}$

\begin{tabular}{|c|c|c|c|c|c|c|c|c|c|}
\hline \multirow[t]{2}{*}{ Products } & \multicolumn{2}{|c|}{ Fresh } & \multicolumn{2}{|c|}{$1^{\text {st }}$ Day } & \multicolumn{2}{|c|}{${ }^{2 \mathrm{rd}}$ Day } & $3^{\text {rd }}$ Day & \multicolumn{2}{|c|}{$4^{\text {th }}$ Day } \\
\hline & $U$ & $\lambda 0 \pi$ & $U 0$ & $>0$ & $\cup 0$ & $>0$ & $\begin{array}{lllll}U & 0 & \nearrow & 0 & \pi\end{array}$ & $U 0$ & $\lambda 0 \pi$ \\
\hline $\mathbf{C}$ & Nil & Nil & Nil & Nil & Nil & Nil & \multirow[t]{3}{*}{ Not acceptable } & - & - \\
\hline C1 & Nil & Nil & Nil & Nil & Nil & Nil & & - & - \\
\hline C2 & Nil & Nil & Nil & Nil & Nil & Nil & & - & - \\
\hline C3 & Nil & Nil & Nil & Nil & Nil & Nil & Nil & \multicolumn{2}{|c|}{ Not acceptable } \\
\hline C4 & Nil & Nil & Nil & Nil & Nil & Nil & Not acceptable & & - \\
\hline Co-efficient & 0 & 0 & 0 & 0 & 0 & 0 & - & - & - \\
\hline t-value & 0 & 0 & 0 & 0 & 0 & 0 & - & - & - \\
\hline
\end{tabular}

- All the values are average of three trials

- Similar superscripts indicates non-significance at the corresponding critical difference on a row

$\mathrm{C}_{0}$ : Control cow milk Dahi

$>\mathrm{C}_{1}$ : Caprine milk Dahi

$>\mathrm{C}_{2}$ : Dahi incorporated with $\beta$-casein BAPs at 1.0 per cent level

$>\mathrm{C}_{3}$ : Dahi incorporated with $\beta$-casein BAPs at 1.5 per cent level

$>\mathrm{C}_{4}$ : Dahi incorporated with $\beta$-casein BAPs at 2.0 per cent level 
Table.4 Free fatty acids and soluble nitrogen content of caprine milk Dahi incorporated with $\beta$-casein BAPs during storage at $30 \pm 1^{\circ} \mathrm{C}$

\begin{tabular}{|c|c|c|c|c|c|c|c|}
\hline \multirow{3}{*}{ Products } & \multicolumn{7}{|c|}{ Storage days } \\
\hline & \multicolumn{2}{|c|}{1} & \multicolumn{2}{|c|}{2} & \multicolumn{2}{|c|}{3} & 4 \\
\hline & $\begin{array}{c}\text { FFA } \\
(\% \text { oleic acid })\end{array}$ & $\begin{array}{c}\text { Soluble } \\
\text { nitrogen } \\
(\%)\end{array}$ & $\begin{array}{c}\text { FFA } \\
(\% \text { oleic acid })\end{array}$ & $\begin{array}{c}\text { Soluble } \\
\text { nitrogen } \\
(\%)\end{array}$ & $\begin{array}{l}\text { FFA } \\
\text { (\% oleic } \\
\text { acid) }\end{array}$ & $\begin{array}{c}\text { Soluble } \\
\text { nitrogen } \\
(\%)\end{array}$ & \multirow{7}{*}{ 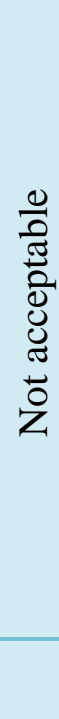 } \\
\hline $\mathbf{C}$ & $5.20^{\mathrm{a}}$ & $0.09^{\mathrm{a}}$ & $11.50^{\mathrm{b}}$ & $0.20^{\mathrm{b}}$ & \multirow{3}{*}{\multicolumn{2}{|c|}{ Not acceptable }} & \\
\hline C1 & $7.8^{\mathrm{a}}$ & $0.14^{\mathrm{a}}$ & $11.60^{\mathrm{b}}$ & $0.17^{\mathrm{b}}$ & & & \\
\hline $\mathrm{C2}$ & $7.6^{\mathrm{a}}$ & $0.12^{\mathrm{a}}$ & $11.58^{\mathrm{b}}$ & $0.15^{\mathrm{b}}$ & & & \\
\hline C3 & $7.3^{\mathrm{a}}$ & $0.09^{\mathrm{a}}$ & $10.74^{\mathrm{b}}$ & $0.10^{\mathrm{b}}$ & $11.30^{\mathrm{b}}$ & $0.17^{\mathrm{b}}$ & \\
\hline $\mathrm{C4}$ & $7.6^{\mathrm{a}}$ & $0.13^{\mathrm{a}}$ & $11.54^{\mathrm{b}}$ & $0.14^{\mathrm{b}}$ & \multicolumn{2}{|c|}{ Not acceptable } & \\
\hline $\mathrm{CD}(\mathrm{P} \leq 0.05)$ & 0.036 & 0.027 & 0.056 & 0.078 & - & - & \\
\hline
\end{tabular}

- All the values are average of three trials

- Similar superscripts indicates non-significance at the corresponding critical difference on a row

$>$ C0: Control cow milk Dahi

$>$ C1: Caprine milk Dahi

$>$ C2: Dahi incorporated with $\beta$-casein BAPs at 1.0 per cent level

$>$ C3: Dahi incorporated with $\beta$-casein BAPs at 1.5 per cent level

$>$ C4: Dahi incorporated with $\beta$-casein BAPs at 2.0 per cent level 
Microbiological quality of caprine milk Dahi incorporated with $\beta$-casein BAPs during storage at $30 \pm 1^{0} \mathrm{C}$

The microbiological quality of caprine milk Dahi incorporated with $\beta$-casein BAPs during storage at room temperature $\left(30 \pm 1^{0} \mathrm{C}\right)$ was presented in Table 4 . The coliform and yeast \& molds counts are absent throughout the storage period of Dahi. The control showed the shelf of 3 days where as 1.5 per cent BAPs incorporated Dahi showed the shelf of 4 days. Similar observation was made by Dardashti et al., (2001), and Manmatha (2014) and Tamime and Robinson, (1985) this may be due the slower lactic fermentation, lesser acidity development, variation in buffering activities and may presence of antibacterial and antioxidative action of BAPs.

In conclusion, the sensory score of cow and caprine milk Dahi of all the samples were decreased during storage period at room temperature. There was significant difference $(p \leq 0.05)$ on all sensory attributes of all the samples with respect to control. C3 sample $\left(1.5 \% \beta_{-C N}\right.$ BAPs) secured significantly higher score than other samples this is mainly because it retained the freshness of product. The development of acidity, release of free fatty acids and soluble nitrogen content were slow found in C3 sample compare to control and other samples. The microbiological examination of Dahi reveals that the coliforms were absent during storage. All samples were unacceptable at the end of $3^{\text {rd }}$ day of storage due to surface discolouration, higher level of synergies and development of off-flavour, hence they are considered as unacceptable whereas C3 sample extends their shelf life up to $4^{\text {th }}$ day of storage under refrigeration $\left(30 \pm 1^{0} \mathrm{C}\right)$. This may be due to slower acidity development, delay in release of free fatty acids, action of antibacterial and anti oxidative activity of BAPs.

\section{Acknowledgement}

The authors acknowledge Karnataka Veterinary, Animal and Fisheries Sciences University, Bidar for provided part time deputation to conduct research work at Dairy Science College, Hebbal, Bengaluru, India.

\section{References}

Aloğlu, H.Ş. and Öner, Z., 2013. The effect of treating goat's milk with transglutaminase on chemical, structural, and sensory properties of labneh. Small Ruminant Research., 109(1): 31-37.

Bradford, M. M., 1976. A rapid and sensitive method for the quantitation of microgram quantities of protein utilizing the principle of protein-dye binding. Analytical Biochemistry., 72 (1-2): 248-254.

Dardashti, A. D, Afshin A, Saeed B, Grce M, Pigac, J. and Marsa V., 2001. Study of coliform, yeast and mold contamination of yogurt in Ghaemshah in lran. Periodicum Biologorum., 103: 183-186.

Fitz Gerald, R. J., 1998. Potential uses of caseinophosphopeptides. International Dairy Journal., 8 (5-6): 451-457.

Hipp, N.J., Groves, M.L., Custer, J.H. and Mcmeekin, T.L., 1952. Separation of $\alpha$ s-, $\beta$-and $\gamma$-Casein. Journal of Dairy Science., 35(3):272-281.

Kamruzzaman, M., Islam, M.N. and Rahman, M.M., 2002. Shelf life of different types of Dahi at room and refrigeration temperature. Pakistan Journal of Nutrition., 1 (6): 234-237.

Manmatha. S.R., 2014. Compositional and Physico-chemical attributes of yoghurt prepared by using caprine milk. M.Sc. Thesis submitted to Karnataka Veterinary Animal Sciences University, Bidar, India.

Mcdonagh, D. and Fitzgerald, R.J., 1998. Production of caseinophosphopeptides (CPPs) from sodium caseinate using a range of commercial

Mudgal, S.P. and Prajapati, J.B., 2017. DahiAn Indian Naturally Fermented Yogurt. 
In Yogurt in Health and Disease Prevention., 353-369.

Nagamani. A., 2013. Characterization and immunomodulatory activity of buffalo milk bio-activity peptides in weaning foods. Ph.D. Thesis submitted to Karnataka Veterinary, Animal and Fisheries Sciences University, Bidar, India.

Naik, L. Mann, B. Bajaj, R. R. B. Sangwan, R.B. and Sharma, R., 2013. Process Optimization for the production of biofunctional whey protein hydrolysates: Adopting response surface methodology. International Journal of Peptide Research Therapeutics., 19:231-237.

Nikil Mahabalashetti, 2017. Development of coconut milk and kiwi fruit enriched dahi.
M.Sc. Thesis submitted to Karnataka Veterinary, Animal and Fisheries Sciences University, Bidar, India.

Snedecor, G.M. and Cochran, W.G., 1983. Statistical Methods. Oxford and IBH Publishing Company., Pp. 60-65.

Tamime, A.Y. and Robinson, R.K., 1985. Yoghurt: science and technology. In: Traditional and Recent developments in yoghurt production. $2^{\text {nd }}$ Edition. CRC Press LLC, Boca Raton, Florida., 234275.

www.nddb.org/information/stats/milkprodindia Yadav, A.K., Singh, J. and Yadav, S.K., 2016. Composition, nutritional and therapeutic values of goat milk: A review. Asian Journal of Dairy and Food Research., $35(2)$.

\section{How to cite this article:}

Devaraja Naik, H., M. Venkatesh and Prabha, R. 2018. Storage Stability of Cow and Caprine Milk Dahi Incorporated with $\beta$ - Casein Bioactive Peptides. Int.J.Curr.Microbiol.App.Sci. 7(11): 20112019. doi: https://doi.org/10.20546/ijcmas.2018.711.228 